\title{
The 2'-O-methyltransferase responsible for modification of yeast tRNA at position 4
}

\author{
MARTHA L. WILKINSON, ${ }^{1}$ SHARON M. CRARY, ${ }^{2}$ JANE E. JACKMAN, ${ }^{1}$ ELIZABETH J. GRAYHACK, ${ }^{1}$ \\ and ERIC M. PHIZICKY' \\ ${ }^{1}$ Department of Biochemistry and Biophysics, University of Rochester School of Medicine, Rochester, New York 14642, USA \\ ${ }^{2}$ Department of Chemistry, DePauw University, Greencastle, Indiana 46135, USA
}

\begin{abstract}
The methylation of the ribose $2^{\prime}-\mathrm{OH}$ of RNA occurs widely in nature and in all stable RNAs and occurs at five positions in yeast tRNA. 2'-O-methylation of tRNA at position 4 is interesting because it occurs in the acceptor stem (which is normally undermodified), it is the only 2'-O-methylation that occurs in the middle of a duplex region in tRNA, the modification is conserved in eukaryotes, and the features of the tRNA necessary for substrate recognition are poorly defined. We show here that Saccharomyces cerevisiae ORF YOL125w (TRM13) is necessary and sufficient for 2'-O-methylation at position 4 of yeast tRNA. Biochemical analysis of the $S$. cerevisiae proteome shows that Trm13 copurifies with 2'-O-methylation activity, using tRNA $^{\mathrm{Gly}(\mathrm{GCC})}$ as a substrate, and extracts made from a trm13- $\Delta$ strain have undetectable levels of this activity. Trm13 is necessary for activity in vivo because tRNAs isolated from a trm13- $\Delta$ strain lack the corresponding 2'-O-methylated residue for each of the three known tRNAs with this modification. Trm13 is sufficient for 2'-O-methylation at position 4 in vitro since yeast Trm13 protein purified after expression in Escherichia coli has the same activity as that produced in yeast. Trm13 protein binds

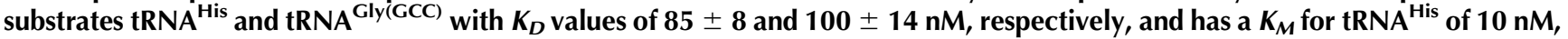
but binds nonsubstrate tRNAs very poorly $\left(K_{D}>1 \mu \mathrm{M}\right)$. Trm13 is conserved in eukaryotes, but there is no sequence similarity between Trm13 and other known methyltransferases.
\end{abstract}

Keywords: tRNA methyltransferase; Trm13; 2'-O-methylation; $S$. cerevisiae; tRNA processing; tRNA modification

\section{INTRODUCTION}

tRNA is the most abundant class of RNA found in the cell, accounting for nearly $90 \%$ of the RNA molecules that are produced in a typical yeast cell. tRNA molecules are extensively modified relative to other classes of RNA. Indeed, 101 of 120 known RNA modifications are found in tRNA (Limbach et al. 1994; Dunin-Horkawicz et al. 2006), and mature nonorganeller tRNA contains an average of 9.3 modified residues (Sprinzl et al. 1998). In the yeast Saccharomyces cerevisiae, 25 modifications have been found within the 34 sequenced cytoplasmic tRNAs, and the average tRNA bears $\sim 13$ modifications (Limbach et al. 1994; Sprinzl et al. 1998).

Reprint requests to: Eric Phizicky, Department of Biochemistry and Biophysics, Box 712, University of Rochester School of Medicine, 601 Elmwood Avenue, Rochester, NY 14642, USA; e-mail: eric_phizicky@ urmc.rochester.edu; fax: (585) 271-2683.

Article published online ahead of print. Article and publication date are at http://www.rnajournal.org/cgi/doi/10.1261/rna.399607.
One modification of particular interest is $2^{\prime}$-O-methylation of ribose. This modification is found in all three major phylogenetic domains and is one of the most common RNA modifications, comprising $\sim 8 \%$ of all tRNA modifications (366/4781) (Grosjean et al. 1995; Sprinzl et al. 1998), as well as a large fraction of the modifications found in rRNA and snRNA (Decatur and Fournier 2002, 2003). Formation of $2^{\prime}$-O-methylated residues is effected by either of two methods. The vast majority of $2^{\prime}-\mathrm{O}-$ methylation of rRNA, and some $2^{\prime}$-O-methylation of snRNA, is catalyzed by a common snoRNP complex comprised of Nop1p, Nop58p, Nop56p, and Snu13p subunits (Schimmang et al. 1989; Tyc and Steitz 1989; Wu et al. 1998; Lafontaine and Tollervey 1999, 2000; Watkins et al. 2000), which derives its specificity from Box C/D-dependent small nucleolar RNAs (snoRNAs) that guide modification to the appropriate base (Balakin et al. 1996; Kiss-Laszlo et al. 1996; Yu et al. 2005). Alternatively, the formation of 2'-O-methylated bases at all sites in eukaryotic and bacterial tRNAs, as well as at some sites in archaeal tRNAs (Clouet-d'Orval et al. 2005; Renalier et al. 2005), requires 
specific methyltransferases that act independently of exogenous guide RNAs.

$2^{\prime}$-O-methylation is found at 13 positions in tRNA, but most commonly at 7 positions in eukaryotes and bacteria (4, $18,32,34,39,44$, and 54), five of which (4, 18, 32, 34, and 44) are found in S. cerevisiae (Sprinzl et al. 1998). The S. cerevisiae genes responsible for three of these modifications are known. Trm7 methylates the ribose at positions 32 and 34 of three tRNAs, and $\operatorname{trm} 7$ mutants have an important role in translational fidelity (Pintard et al. 2002b). Trm3 modifies $\mathrm{G}_{18}$ on 10 of the 34 sequenced tRNAs (Cavaille et al. 1999), and, like many other modification proteins that act at remote sites from the anticodon (Hopper and Phizicky 2003), disruption of the gene has little obvious effect on growth or translation (Cavaille et al. 1999).

We are interested in methylation of ribose $2^{\prime}-\mathrm{OH}$ at position 4 of tRNA. This modification is interesting to study for four reasons. First, this modification is one of only a few that occurs in the amino acid acceptor stem of tRNA. The acceptor stem accounts for only $1.7 \%$ of all tRNA modifications, although it comprises $18 \%$ of the nucleotides of tRNA; moreover, 2'-O-methylation is one of only four modifications that are found in the acceptor stem. Second, this modification is one of very few $2^{\prime}$-O-methylations found in the middle of a duplex region. Of the 422 known occurrences of $2^{\prime}$-O-methylation found among characterized tRNAs (Sprinzl et al. 1998), 18 occur at position 4 in the middle of the acceptor stem, and only two other 2'-O-methylated residues are found in the middle of stems (at positions 29 and 64, within the anticodon stem and the $\mathrm{T}$ stem, respectively). Third, although $2^{\prime}$-O-methylation at position 4 is not common, this modification is widely conserved in eukaryotes, including humans. Fourth, there is no apparent common feature among tRNAs that are 2'-O-methylated at this position, although there must be high specificity, since only three of 34 sequenced tRNAs in $S$. cerevisiae bear this modification: $\mathrm{tRNA}^{\text {His }}$, $\mathrm{tRNA}^{\text {Pro }}$, and tRNA ${ }^{\text {Gly(GCC) }}$ (Fig. 1).

We report here that the $S$. cerevisiae protein encoded by ORF YOL125w (now called TRM13) is responsible for $2^{\prime}$ O-methylation of tRNA at position 4 in vitro and in vivo and that one feature important for Trm13 selectivity appears to be the binding of tRNA substrates. Trm13 exhibits no obvious similarity to other known methyltrans- ferases and may therefore be a member of a previously undescribed methyltransferase family.

\section{RESULTS}

\section{Identification of a yeast ORF associated with $2^{\prime}$-O-methylation of position 4 of tRNA Gly(GCC) $^{\text {(G) }}$}

To identify the protein responsible for 2 '-O-methylation at position 4 of tRNA, we biochemically screened the yeast proteome with tRNA ${ }^{\mathrm{Gly}(\mathrm{GCC})}$ from $S$. cerevisiae (Fig. 1A), which is known to bear a $2^{\prime}$-O-methylcytidine $(\mathrm{Cm})$ at position 4 (Yoshida 1973). To detect 2'-O-methylation, we transcribed a tRNA ${ }^{\text {Gly }}$ gene construct with $\left[\alpha-{ }^{32} \mathrm{P}\right] \mathrm{ATP}$; incubated the labeled tRNA with a protein source and $S$-adenosyl-methionine (SAM); treated the RNA with RNase $\mathrm{A}, \mathrm{RNase} \mathrm{T} 2$, and phosphatase, to generate $\mathrm{CmA}$ arising from methylation of the $2^{\prime}-\mathrm{OH}$ between $\mathrm{C}_{4}$ and $\mathrm{A}_{5}$, and $\mathrm{P}_{\mathrm{i}}$ from unreacted substrate and other labeled residues; and separated the $\mathrm{CmA}$ and $\mathrm{P}_{\mathrm{i}}$ by thin layer chromatography (Fig. 1B). We then screened the $S$. cerevisiae proteome with this assay, using proteins purified from the movable open 
reading frame (MORF) library of yeast strains, each of which expresses a yeast ORF fused at its $C$ terminus to a tri-partite affinity tag (Gelperin et al. 2005). To do this, we used the biochemical genomics approach described previously for another genomic library (Xing et al. 2002; Gu et al. 2003; Jackman et al. 2003; Alexandrov et al. 2005), employing pools of purified proteins. We first assayed pools of purified ORF-fusion proteins, each derived from 96 strains expressing ORFs, and found that pool 45 has the appropriate 2'-O-methyltransferase activity (Fig. 1C). We then assayed subpools of purified ORF-fusion proteins derived from the strains in microtiter plate 45 and found activity in Row G and column 11, indicating that ORF YOL125w in the strain at this position is associated with the activity (Fig. 1D). To confirm this assignment, we showed that the purified protein from this MORF strain had activity (data not shown) and sequenced the plasmid DNA from the MORF strain to confirm its identity. We assigned the name TRM13 to ORF YOL125w because, as shown below, this ORF encodes the $2^{\prime}$-O-methyltransferase that modifies residue 4 of tRNA in vitro and in vivo.

\section{Trm13 (YOL125w) protein is necessary for 2'-O-methylation of position 4 of tRNA ${ }^{\text {Gly }}$ in vitro and in vivo}

To determine if $\operatorname{Trm} 13$ is required for the 2'-O-methylation of tRNA, we prepared crude extracts from a MAT $\alpha$ trm13- $\Delta$ strain, an otherwise isogenic control deletion strain (MAT $\alpha$ ynr069c- $\Delta$ ) and a related wild-type TRM $13^{+} / T_{R M} 13^{+}$control strain, and compared their activities. As measured by protein titrations with the tRNA ${ }^{\text {Gly }}$ substrate, $30 \mu \mathrm{g}$ extract from the MAT $\alpha$ trm13- $\Delta$ strain has undetectable levels of $2^{\prime}$-O-methyltransferase activity, whereas activity is easily detected from both control strains containing Trm13p, using as little as $0.3 \mu \mathrm{g}$ extract (Fig. 2A). Thus, $\operatorname{Trm} 13$ is necessary for $2^{\prime}$-O-methylation of tRNA ${ }^{\text {Gly }}$ in vitro. We show below that this modification occurs at position 4 .

To determine if Trm13 is responsible for the $2^{\prime}$-Omethylation at position 4 of tRNA in vivo, we purified individual tRNAs from both the trm13- $\Delta$ strain and the wild-type control strain and analyzed their nucleoside composition using HPLC. As shown in Figure 2B-D, each of the three individual tRNAs known to have a $2^{\prime}$-Omethylated residue at position 4 has the expected $2^{\prime}$-Omethylated nucleoside ( $\mathrm{Cm}$ for tRNA ${ }^{\text {Pro }}$ and tRNA ${ }^{\text {Gly }}$ and Am for $\mathrm{tRNA}^{\mathrm{His}}$ ), as measured by appearance of a peak in the expected location (Gehrke and Kuo 1989) and by the UV absorption spectrum of the corresponding peak. By contrast, each of the corresponding tRNAs from the trm13- $\Delta$ strain lack the 2'-O-methylated residues (Fig. 2B-D). Moreover, quantification of the nucleoside composition of these tRNAs revealed that the trm $13-\Delta$ strain had $<1 \%$ of the corresponding 2'-O-methylated nucleosides (Table 1), whereas other nucleosides were present at the expected
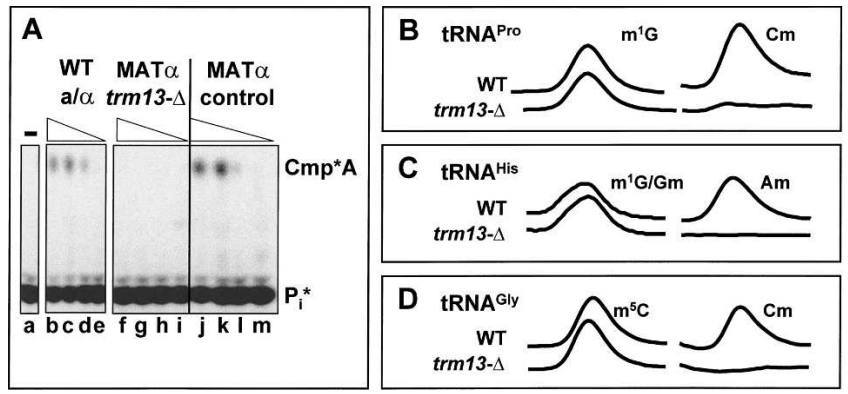

FIGURE 2. Trm13 is required in vitro and in vivo for $2^{\prime}-\mathrm{O}-$ methylation of tRNA. (A) Extract from a trm13- $\Delta$ strain has no detectable 2'-O-methyltransferase activity. A MAT $\alpha$ trm13- $\Delta$ strain, a control MAT $\alpha$ strain $(y n r 069 c-\Delta)$, and a control diploid $\left(T R M 13^{+}\right.$/ $T R M 13^{+}$) strain were grown to mid-log phase in YP media containing $2 \%$ glucose, and extracts were assayed for 2'-O-methyltransferase activity for $2 \mathrm{~h}$ at $30^{\circ} \mathrm{C}$ with $\left[\alpha-{ }^{32} \mathrm{P}\right]$ labeled tRNA ${ }^{\text {Gly }}$ as described in Figure 1, with decreasing amounts of crude extract (by factors of 10, beginning with $\sim 30 \mu \mathrm{g}$ protein). ( $B-D)$ A trm 13- $\Delta$ strain lacks 2 '-Omethylated residues expected at position 4 of tRNA. tRNA ${ }^{\text {Pro }}(B)$, tRNA $^{\text {His }}(C)$, and tRNA ${ }^{\text {Gly }}(D)$ were purified from wild-type and trm13- $\Delta$ strains, and their nucleosides were resolved by HPLC as described in Materials and Methods. tRNAs isolated from wild type contain all expected modifications as annotated in the literature (Yoshida 1973; Keith et al. 1983), whereas tRNAs isolated from trm13$\Delta$ strains contain all expected modifications except the 2 '-O-methylated residue. Traces shown in the left panel for each tRNA describe a sample modification whose quantification is unaffected by the deletion of TRM13. Traces shown in the right panel correspond to the 2'-O-methylated nucleosides found in each tRNA.

molar levels. Since each of these tRNAs has only a single 2'-O-methylated residue and this residue is known to be at position 4 (Yoshida 1973; Keith et al. 1983), we conclude that $\operatorname{Trm} 13$ is responsible for the production of $2^{\prime}-\mathrm{O}-$ methylated nucleosides at position 4 in vivo.

To confirm the position of the 2'-O-methylated residue that is lost in a trm13- $\Delta$ strain, we used primer extension to assay $2^{\prime}$-O-methylation of tRNA ${ }^{\text {His }}$. As shown in Figure 3, there is a clear pause at position 5 in the primer extension of tRNA $^{\text {His }}$ from wild-type cells, but no corresponding signal in the primer extension of tRNA ${ }^{\text {His }}$ from the trm13- $\Delta$ strain. Since, in addition, the band is only observed at low NTP concentrations (data not shown), we conclude that the band is a pause, as expected of 2'-O-methylation (Maden et al. 1995).

\section{Trm13 is sufficient for 2'-O-methylation at position 4 on RNA $^{\text {Gly }}$ in vitro}

To determine if $\operatorname{Trm} 13$ is sufficient for activity, we expressed and purified the protein from Escherichia coli and compared its activity to that produced from yeast, using a tRNA ${ }^{\text {Gly }}$ substrate uniquely labeled at the phosphate between $\mathrm{C}_{4}$ and $\mathrm{A}_{5}$ to enhance the sensitivity of the activity assay (Fig. 4A). To this end, we cloned TRM13 into a pET14b-based vector and purified the $\mathrm{His}_{6}$-Trm13 protein expressed in E. coli, resulting in a preparation that was at 
TABLE 1. Quantification of nucleoside composition of tRNA purified from trm13- $\Delta$ and control strain by HPLC analysis

\begin{tabular}{lcccr}
\hline tRNA & Bases & Expected & WT & trm13- \\
\hline tRNA $^{\text {Gly }}$ & $\Psi$ & 4 & 3.50 & 3.15 \\
& $\mathrm{~m}^{5} \mathrm{C}$ & 2 & 1.74 & 1.48 \\
& $\mathrm{Cm}$ & 1 & 1.16 & $<0.01$ \\
& $\mathrm{~m}^{1} \mathrm{G}$ & 2 & 1.15 & 1.33 \\
& $\mathrm{DHU}$ & 2 & 1.91 & 1.71 \\
& $\mathrm{~T}$ & 1 & 0.55 & 0.72 \\
tRNA $^{\text {His }}$ & $\mathrm{Am}$ & 1 & 0.95 & 0.01 \\
tRNA $^{\text {Pro }}$ & $\mathrm{Cm}$ & 1 & 0.77 & $<0.01$ \\
\hline
\end{tabular}

least $60 \%$ pure as measured by SDS-PAGE (data not shown). A corresponding purification of the yeast Trm13MORF protein resulted in protein that was $\sim 50 \%$ pure and comprised of a doublet polypeptide as visualized by SDSPAGE (data not shown).

Comparison of the activity in crude extracts (CE) and purified proteins leads to two conclusions: First, the activity of $\mathrm{His}_{6}$-Trm 13 protein purified from E. coli is comparable to that of Trm13 protein prepared from yeast, based on approximate specific activity measurements (Fig. 4B; Table 2). Thus, Trm13 is sufficient for activity on its own without additional S. cerevisiae proteins or RNA. Second, the yield of activity for both purifications is reasonable $(20 \%$ for the yeast Trm13-MORF protein and 30\% for the His6YOL125w protein from E. coli), suggesting that we are not losing necessary cofactors during the purification.

To show that the modification catalyzed by Trm 13 protein is indeed $2^{\prime}$-O-methylation and only occurs at a single position, we incubated the $\mathrm{His}_{6}$-Trm 13 protein purified from E. coli with unlabeled tRNA ${ }^{\text {Gly }}$ and analyzed products by HPLC after digestion to form nucleosides. After incubation of $3.2 \mu \mathrm{M}$ protein and $10 \mu \mathrm{M}$ tRNA ${ }^{\text {Gly }}$ for $2 \mathrm{~h}$, we observed the formation of $0.93 \mathrm{~mol} \mathrm{2}$-O-methylcytidine per mole tRNA, as determined by observation of a nucleoside with the mobility and the spectrum of $\mathrm{Cm}$, and quantification of the yield (Fig. 4C). Since Trm13 can modify position 4 (Fig. $4 \mathrm{~B}$ ), and $\sim 1 \mathrm{~mol}$ of the $2^{\prime}$-Omethylcytidine product is produced per mole of tRNA substrate, we conclude that Trm13 protein catalyzes $2^{\prime}$-Omethylation of residue 4 and most likely of no other residue. Based on this analysis of catalytic activity of Trm 13 and the in vivo analysis of trm13- $\Delta$ strains described above, we conclude that Trm13 is both necessary and sufficient for $2^{\prime}$-O-methylation at position 4 of substrate tRNAs.

\section{Trm13 recognizes its tRNA substrates by binding}

One important question about Trm13 tRNA Nm 4 2'-Omethyltransferase is the nature of the common features of its tRNA substrates. Trm13 protein recognizes and modifies residue 4 of tRNA ${ }^{\text {Gly(GCC) }}$, $\mathrm{tRNA}^{\mathrm{His}}$, and $\mathrm{tRNA}^{\text {Pro }}$, but these tRNAs have no obvious features in common that are not also shared with some of the 31 other yeast tRNAs that are not $2^{\prime}$-O-methylated at residue 4 .

To begin to address this question, we investigated the binding of tRNA to Trm13. Trm13 binds its substrate tRNA $^{\text {His }}$ efficiently, with a $K_{D}$ value of $85 \pm 8 \mathrm{nM}$, measured using an electrophoretic mobility shift assay (EMSA), with Trm13 protein in excess over tRNA (Fig. 5A,C). Using the same assay, we demonstrated that Trm13 also binds its substrate tRNA $^{\text {Gly }}$ efficiently, with a $K_{D}=100 \pm 14 \mathrm{nM}$ (Fig. 5C). The observed $K_{D}$ values for these tRNA species were not dependent on the amount of tRNA in the binding experiment and therefore reflect an apparent binding constant, not simply a titration artifact.

Comparison of binding to nonsubstrate tRNAs demonstrates that Trm13 binds preferentially to substrate tRNAs. As shown in Figure 5, tRNA ${ }^{\text {Phe }}$ (Fig. 5B,C) and tRNA ${ }^{\text {Leu }}$ (Fig. 5C) bind very poorly $\left(K_{D}\right.$ values estimated at $>1000$ $\mathrm{nM}$ and $>3000 \mathrm{nM}$, respectively). Similar binding differences between substrate and nonsubstrate tRNAs are observed whether or not $\mathrm{Mg}^{++}$is present in the gel buffer. In addition, binding to nonsubstrate tRNAs is as weak as binding to an equivalent amount of poly $(\mathrm{A})$ (data not shown). Thus, it appears that $\operatorname{Trm} 13$ protein efficiently discriminates substrates from nonsubstrates by binding.

The steady-state kinetic parameters for Trm13 activity with tRNA $^{\text {His }}$ demonstrate that Trm13 efficiently catalyzes $2^{\prime}$-O-methylation on this substrate. To obtain these parameters, we assayed $2^{\prime}-\mathrm{O}$-methylation of a transcribed tRNA $^{\text {His }}$ substrate singly labeled between $C_{3}$ and $A_{4}$, followed by $\mathrm{P} 1$ nuclease treatment and thin-layer chromatography to separate pAm from $\mathrm{pA}$ and quantification by a
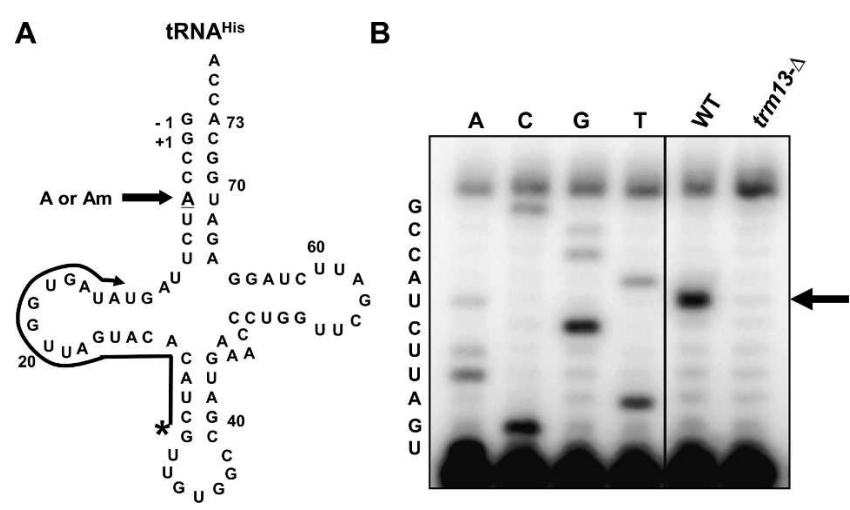

FIGURE 3. tRNA $^{\text {His }}$ from a trm13- $\Delta$ strain lacks $2^{\prime}$-O-methylation at position 4. (A) Clover leaf structure of tRNA ${ }^{\text {His }}$. The position of the primer used for primer extension analysis is indicated by the arrow. The horizontal arrow indicates the base expected to be $2^{\prime}$-Omethylated. (B) Primer extension to assess $2^{\prime}$-O-methylation of tRNA $^{\text {His }}$ at position 4. Low-molecular-weight RNA derived from wild-type or trm13- $\Delta$ strains, as indicated, was analyzed by primer extension using the primer shown in panel $A$. Lanes A, C, G, T contain the indicated dideoxynucleotide species to generate a sequencing ladder for tRNA ${ }^{\text {His }}$, with the expected sequence as indicated. The arrow indicates the position of the expected primer extension stop due to the presence of the 2'-O-methylated nucleotide. 
A

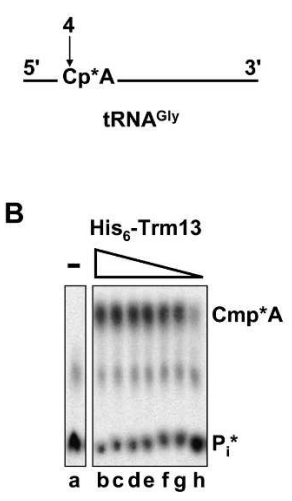

C

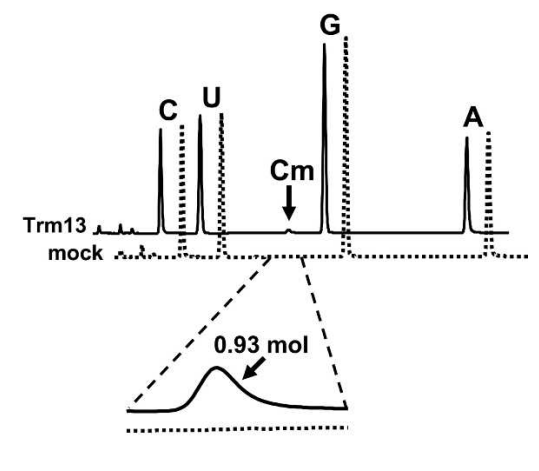

FIGURE 4. Purified $\mathrm{His}_{6}$-Trm13 protein catalyzes formation of $1 \mathrm{~mol}$ of 2'-O-methylcytidine at position 4 of tRNA ${ }^{\text {Gly }}$ in vitro. $(A)$ Schematic of substrate tRNA ${ }^{\text {Gly }}$ bearing a single labeled ${ }^{32} \mathrm{P}$ between $\mathrm{C}_{4}$ and $\mathrm{A}_{5}\left(\mathrm{C}_{4}{ }^{*}-\mathrm{tRNA}{ }^{\mathrm{Gly}}\right)$. (B) $\mathrm{His}_{6}-\mathrm{Trm} 13$ protein purified from E. coli catalyzes $2^{\prime}$-O-methylation of residue 4 of tRNA ${ }^{\text {Gly }}$. Reaction mixtures containing a labeled $\mathrm{C}_{4}{ }^{*}$-tRNA ${ }^{\text {Gly }}$ substrate and decreasing concentrations of purified $\mathrm{His}_{6}-\mathrm{Trm} 13$ protein (by factors of 10 , beginning with $0.68 \mathrm{mg} / \mathrm{mL}$ ) were incubated for $1.5 \mathrm{~h}$ at $30^{\circ} \mathrm{C}$, and then RNA was analyzed as described in Materials and Methods. $(C)$ $\mathrm{His}_{6}-\mathrm{Trm} 13$ protein catalyzes formation of $1 \mathrm{~mol}$ of $2^{\prime}$-O-methylcytidine per mole of tRNA ${ }^{\text {Gly }}$. His $_{6}$-Trm13 protein $(3.2 \mu \mathrm{M})$ or buffer was incubated with $10 \mu \mathrm{M}(2 \mathrm{nmol})$ unlabeled transcribed tRNA ${ }^{\text {Gly }}$ for $2 \mathrm{~h}$, and RNA was treated with P1 nuclease and phosphatase to form nucleosides, which were resolved by HPLC. The extra product formed with $\operatorname{Trm} 13$ protein matches the accepted retention time and UV spectrum for 2'-O-methylcytidine (Gehrke and Kuo 1989). The expanded area shows a high-resolution view of the region of the HPLC trace corresponding to 2'-O-methylcytidine.

PhosphorImager to measure activity (Fig. 6A). Although this synthetic tRNA ${ }^{\text {His }}$ substrate lacks the $\mathrm{G}_{-1}$ residue that is normally added by tRNA ${ }^{\text {His }}$ guanylyltransferase (Thg1) to tRNA ${ }^{\text {His }}$ in vivo, we note that tRNA ${ }^{\text {His }}$ isolated from Thg1-depleted cells lacks $G_{-1}$ but is fully modified at position 4 in vivo ( $\mathrm{Gu}$ et al. 2005). A plot of the linear initial rates measured at each substrate concentration follows Michaelis-Menten kinetics (Fig. 6B), and a fit of these data yields a $K_{M}$ of $10 \mathrm{nM}$ and $k_{\text {cat }}$ of $0.24 \mathrm{~min}^{-1}$, which combine to yield a $k_{c a t} / K_{M}$ of $4.0 \times 10^{5} \mathrm{M}^{-1} \mathrm{sec}^{-1}$.

\section{Trm13 protein is highly conserved within eukaryotes and is not similar to other methyltransferases}

Analysis of the Trm13 protein sequence by BLAST reveals a number of predicted eukaryotic proteins with homology with $\operatorname{Trm} 13$, but no proteins with homology in organisms from other domains. Homologs are found widely in fungi (including Candida glabrata [E value $\mathrm{e}^{-72}, 41 \%$ identity, 57\% similarity]; Kluyveromyces lactis, $\mathrm{e}^{-65}$; Candida albicans, $\mathrm{e}^{-39}$; and Schizosaccharomyces pombe, $\mathrm{e}^{-15}$ ), vertebrates (such as Homo sapiens, $\mathrm{e}^{-26} ;$ Mus musculus, $\mathrm{e}^{-26}$; Xenopus laevis, $\mathrm{e}^{-29}$; Canis familiaris, $\mathrm{e}^{-27}$; and Danio rerio, $\mathrm{e}^{-26}$ ), invertebrates (such as Drosophila melanogaster, $\mathrm{e}^{-30}$ Anopheles gambiae, $\mathrm{e}^{-26}$; and Caenorhabditis elegans, $\mathrm{e}^{-15}$ ), plants (such as Arabidopsis thaliana, $\mathrm{e}^{-24}$; and Oryza sativa, $\mathrm{e}^{-12}$ ), and protists (such as Trypanosoma cruzi, $\mathrm{e}^{-14}$, $22 \%$ identity, $39 \%$ similarity). Although the overall similarity between yeast Trm13 and its protein homologs from other organisms is not extremely high, clusters of completely conserved amino acids are observed over the entire sequence (Fig. 7), perhaps indicating a common active site for 2'-O-methylation in the context of a varied structural environment between different members of this protein family. The widespread distribution of putative $\operatorname{Trm} 13$ homologs in eukaryotes contrasts with its absence in archaea and bacteria and is consistent with the known distribution of 2'-O-methylation at position 4 in eukaryotic tRNA, but not in tRNA from other domains.

The $\operatorname{Trm} 13$ protein family appears to represent a new family of methyltransferases. There is no obvious homology with other methyltransferases, based on BLAST search. Moreover, there is little, if any, similarity between $\operatorname{Trm} 13$ protein and other tRNA 2'-O-methyltransferases identified in yeast (Cavaille et al. 1999; Pintard et al. 2002a,b; Lapeyre and Purushothaman 2004), as determined by pairwise BLAST, or with the RrmJ/fibrillarin superfamily of 2'-Omethyltransferases (Feder et al. 2003). Since Trm13 protein is described in the PFAM database as a domain of unknown function (DUF 715) and all of the putative Trm13 protein homologs are annotated as novel or hypothetical proteins, the Trm13 family might represent an additional family of methyltransferase proteins, although the low degree of similarity among methyltransferases within the family precludes a definitive statement in this regard (Schubert et al. 2003).

We note that trm13- $\Delta$ strains do not have an obvious growth defect. No growth difference was observed between trm13- $\Delta /$ trm13- $\Delta$ strains and its otherwise isogenic $T R M 13^{+} / T R M 13^{+}$parent when grown on rich media (YP) containing different fermentable sugars (raffinose, galactose, and glucose) or nonfermentable carbon sources (ethanol and glycerol), or in synthetic complete media containing glucose, at a variety of temperatures including $18^{\circ} \mathrm{C}, 25^{\circ} \mathrm{C}, 30^{\circ} \mathrm{C}, 33^{\circ} \mathrm{C}, 35^{\circ} \mathrm{C}$, and $37^{\circ} \mathrm{C}$ (data not shown).

TABLE 2. Analysis of the specific activity of Trm13 protein purified from yeast or $E$. coli

\begin{tabular}{|c|c|c|c|}
\hline & Protein source & Total units $^{\mathrm{a}}$ & 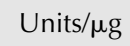 \\
\hline \multirow[t]{3}{*}{ Yeast } & wt CE & $1 \times 10^{6}$ & $1.3 \times 10^{1}$ \\
\hline & TRM13-MORF CE & $2.5 \times 10^{8}$ & $5.6 \times 10^{3}$ \\
\hline & Trm13-MORF protein & $5 \times 10^{7}(20 \%)^{b}$ & $8.3 \times 10^{5}$ \\
\hline \multirow[t]{2}{*}{ E. coli } & $\mathrm{His}_{6}-\mathrm{TRM} 13 \mathrm{CE}$ & $1 \times 10^{10}$ & $3.3 \times 10^{6}$ \\
\hline & $\mathrm{His}_{6}-\mathrm{Trm} 13$ protein & $3 \times 10^{9}(30 \%)^{b}$ & $2.9 \times 10^{6}$ \\
\hline
\end{tabular}

${ }^{a}$ Units calculated as $50 \%$ conversion of substrate to product in $2 \mathrm{~h}$ at $30^{\circ} \mathrm{C}$ under standard conditions.

${ }^{b}$ Numbers in parentheses reflect total percent yield of activity in the purified protein compared to the corresponding crude extract. 
A

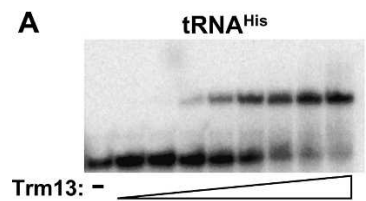

B

tRNA ${ }^{\text {Phe }}$
Trm13:
C

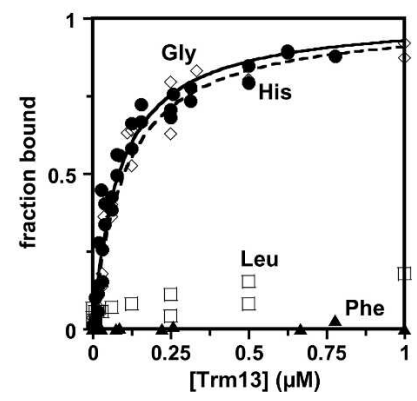

FIGURE 5. Trm 13 protein binds tRNA substrates with higher affinity than nonsubstrate tRNAs. $(A, B)$ Analysis of binding by EMSA. tRNA $^{\text {His }}(0.3 \mathrm{nM})$ and tRNA ${ }^{\text {Phe }}(0.3 \mathrm{nM})$ were incubated with varying amounts of $\mathrm{His}_{6}$-Trm13 protein in the presence of $10 \mu \mathrm{g} / \mathrm{mL}$ poly(A) RNA and electrophoresed on a 5\% acrylamide gel as described in Materials and Methods. $\mathrm{His}_{6}-\mathrm{Trm} 13$ protein varied from $2 \mu \mathrm{M}$ to $0.9 \mathrm{nM}$ (by factors of 3 ). The first lane in each panel contains no added Trm13 protein. $(C)$ Determination of binding constants. The fraction of total RNA bound in each EMSA assay as shown in panel $A$ was quantified by a PhosphorImager and plotted as a function of Trm13 protein concentration $\left(-\diamond_{-}\right.$, tRNA ${ }^{\text {Gly }} ;-\bullet-$, tRNA $^{\text {His }} ;-\square-$, tRNA ${ }^{\text {Leu}}$; and - $\boldsymbol{\Delta}-$, tRNA $\left.^{\text {Phe }}\right)$. For tRNA ${ }^{\text {His }}$ and tRNA ${ }^{\text {Gly }}$, the resulting data were well fit by a single binding isotherm, and apparent binding constants were determined to be $85 \pm 8 \mathrm{nM}$ for tRNA ${ }^{\text {His }}$ and $100 \pm 14 \mathrm{nM}$ for tRNA ${ }^{\text {Gly }}$. Since little or no apparent binding is observed for tRNA $^{\text {Leu }}$ and tRNA $^{\text {Phe }}$ at even the highest protein concentrations tested, we can estimate lower limits to the $K_{D}$ for these tRNA species of $>1 \mu \mathrm{M}$ and $>3 \mu \mathrm{M}$, respectively.

\section{DISCUSSION}

We have described several lines of evidence demonstrating that the protein encoded by $S$. cerevisiae ORF YOL125w (now called Trm13 protein) is responsible for 2'-Omethylation of tRNA ${ }^{\mathrm{Gly}(\mathrm{GCC})}$, $\mathrm{tRNA}^{\mathrm{His}}$, and $\mathrm{tRNA}^{\text {Pro }}$ at residue 4 . Trm13 protein copurifies with 2'-O-methyltransferase activity during screening of a genomic collection of purified S. cerevisiae fusion proteins from the MORF genomic library (Gelperin et al. 2005) when assayed with labeled tRNA ${ }^{\mathrm{Gly}(\mathrm{GCC})}$ and $S$-adenosylmethionine as methyl donor (Fig. 1). Trm13 protein is necessary for $2^{\prime}-\mathrm{O}$ methylation at position 4 in vitro since a crude extract of a trm13- $\Delta$ strain has no detectable 2'-O-methyltransferase activity, $<1 \%$ of that observed in extracts of wild-type cells (Fig. 2). Trm13 is required in vivo since each of three tRNAs that are known to have 2'-O-methylated residues at position 4 lack the corresponding modified residues when isolated from a trm13- $\Delta$ strain (Figs. 2,3; Table 1). Trm13 protein is sufficient for activity since yeast His6-Trm 13 protein purified from E. coli is as active as Trm13-fusion protein purified from yeast (Table 2), 2'-O-methylates position 4 of a specifically labeled tRNA ${ }^{\text {Gly }}$ substrate, and methylates the same residue of an unlabeled tRNA ${ }^{\text {Gly }}$ substrate with molar efficiency (Fig. 4). These data demonstrate that $\operatorname{Trm} 13$ is both necessary and sufficient for $2^{\prime}$-O-methylation of substrate tRNAs at position 4 in vitro and in vivo.
Our analysis of Trm13 protein conservation suggests that Trm13 may be part of a new family of methyltransferases found within eukaryotes (Fig. 7), consistent with the known eukaryotic distribution of 2'-O-methylated residues at the 4 position of tRNA (Sprinzl et al. 1998), although the large variations among members of this family and other methyltransferase families precludes a definitive conclusion in this regard (Schubert et al. 2003). The lack of similarity between the Trm13 family and other known methyltransferases and 2'-O-methyltransferases suggests a novel mechanism for catalysis and/or substrate recognition for this protein family or, alternatively, that subtle mechanistic or structural similarities exist between $\operatorname{Trm} 13$ and other known methyltransferases. Moreover, the variations within the Trm13 family may imply that some proteins in the family have slightly altered activities or substrate recognition properties. Presumably the differences in substrate modification for the Trm13 family are found in the structure of the tRNA substrates themselves, since there is no obvious pattern among the identity of tRNAs containing a $2^{\prime}$-Omethylated residue at position 4 or the base that is modified. $\mathrm{tRNA}^{\mathrm{Gly}}$ is the most common species with this modification, with seven occurrences in yeast, plants, and humans; followed by five tRNA ${ }^{\text {Pro }}$ species found in fungi and mouse; two tRNA $^{\text {Val }}$ and two tRNA ${ }^{\text {Ser }}$ found exclusively in Drosophila melanogaster; and two tRNA ${ }^{\text {His }}$ in S. cerevisiae. Furthermore, all four bases are found to be $2^{\prime}$-O-methylated at position 4 in the sequenced tRNAs, including two instances of $\mathrm{Gm}$, seven of Um, seven of $\mathrm{Cm}$, and two of Am. It is
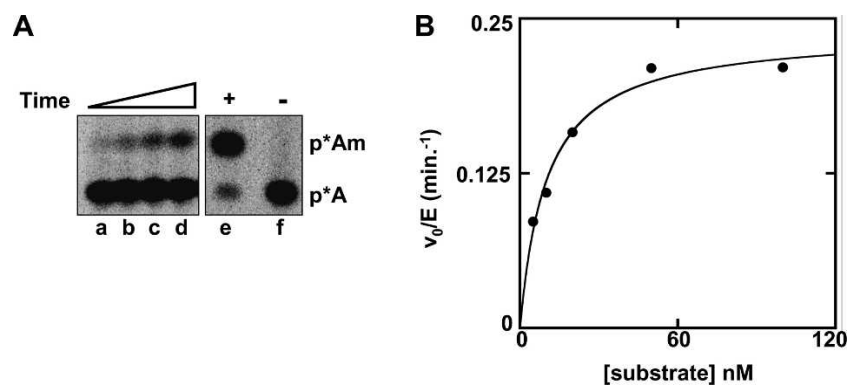

FIGURE 6. Kinetic parameters for $\mathrm{His}_{6}-\mathrm{Trm} 132^{\prime}-\mathrm{O}$-methyltransferase activity with $\mathrm{tRNA}^{\mathrm{His}}$. $\mathrm{His}_{6}$-Trm13 protein $(0.5 \mathrm{nM})$ was incubated with $\mathrm{C}_{3}{ }^{*}$-tRNA ${ }^{\mathrm{His}}$ at different concentrations $(5 \mathrm{nM}, 10 \mathrm{nM}, 20 \mathrm{nM}$, $50 \mathrm{nM}$, and $100 \mathrm{nM}$ ) for $2.5-20 \mathrm{~min}$ at $30^{\circ} \mathrm{C}$ and analyzed for $2^{\prime}-\mathrm{O}-$ methylation by TLC as described in Materials and Methods. (A) Representative time course of $2^{\prime}-\mathrm{O}$-methyltransfease activity of $\mathrm{His}_{6^{-}}$ Trm13 protein with tRNA ${ }^{\text {His }}$. $2^{\prime}$-O-methyltransferase activity was assayed with $0.5 \mathrm{nM}$ Trm 13 and $5 \mathrm{nM}$ tRNA ${ }^{\mathrm{His}}$ at (lane a) $2.5 \mathrm{~min}$, (lane b) $5 \mathrm{~min}$, (lane c) $10 \mathrm{~min}$, (lane d) $20 \mathrm{~min}$; (lane e) the results of reaction with $100 \mathrm{nM}$ tRNA ${ }^{\text {His }}$ and $920 \mathrm{nM} \mathrm{His}_{6}-\mathrm{Trm} 13$ protein for 20 min, showing that all the substrate can react; (lane f) $100 \mathrm{nM}^{\mathrm{tRNA}}{ }^{\text {His }}$ with no Trm13 protein for $20 \mathrm{~min}$. (B) Determination of steady-state kinetic parameters for Trm13 2'-O-methyltransferase activity with tRNA $^{\text {His }}$. Trm13-catalyzed $2^{\prime}$-O-methylation of $\mathrm{tRNA}^{\text {His }}$ occurs with a steady-state $k_{\text {cat }}=0.24 \mathrm{~min}^{-1}, K_{M}=10 \mathrm{nM}$, and $k_{\text {cat }} / K_{M}=4.0 \times$ $10^{5} \mathrm{M}^{-1} \mathrm{sec}^{-1}$, as determined by fit of the data to the MichealisMenten steady-state rate equation (Materials and Methods). 


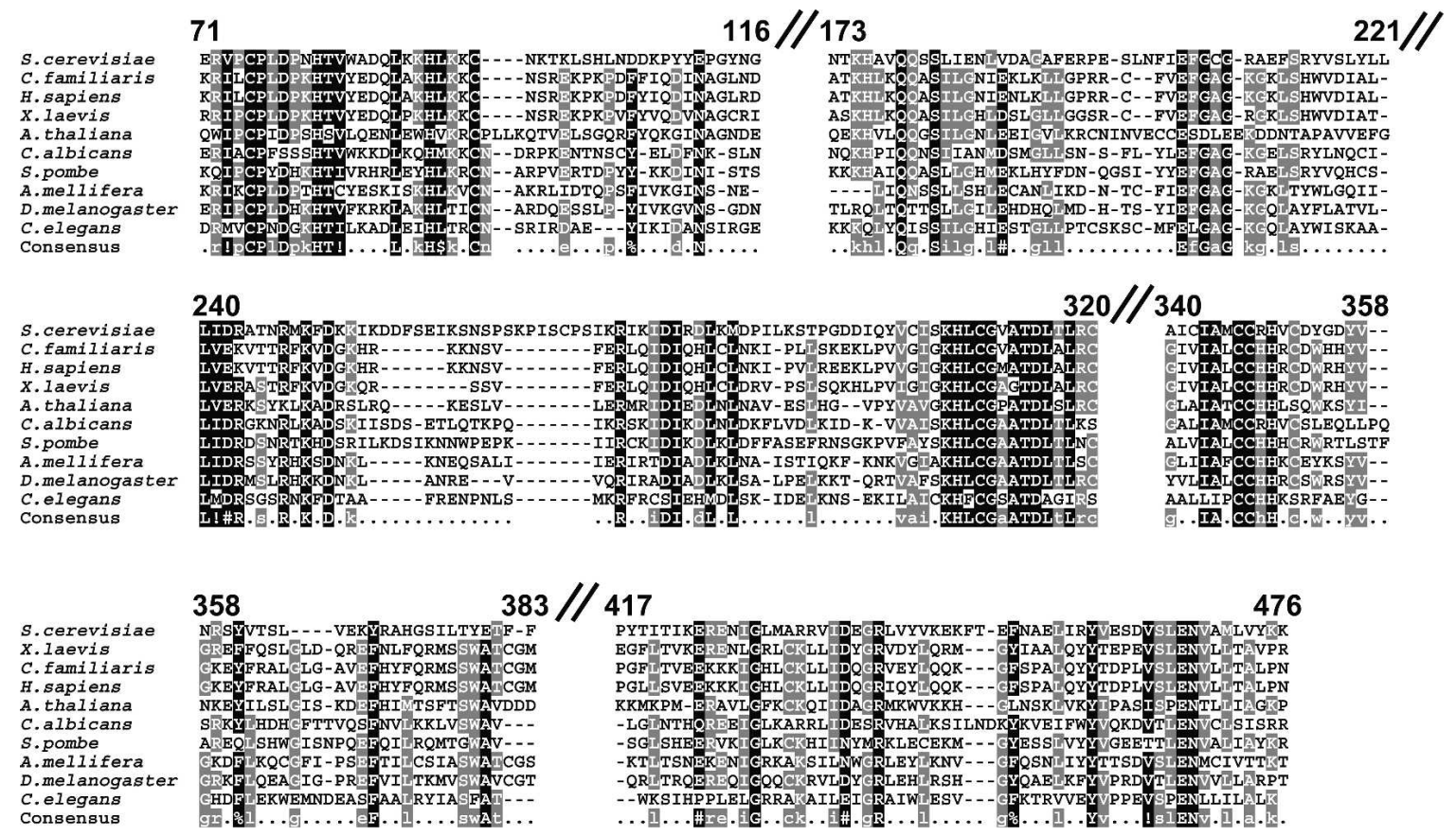

FIGURE 7. Alignment of Trm13 homologs. Homologs of Trm13 were identified by BLAST search (Altschul et al. 1997) and sequences from several representative species, as indicated next to each sequence line, were aligned using Multalin (Corpet 1988) with the following parameters: gap weight $=6$ and gap length weight $=2$. Dark shading indicates $>80 \%$ consensus; light shading indicates $>50 \%$ consensus at each position. For clarity, several regions with very low homology were omitted from this alignment; these breaks in the sequence are indicated with double hash marks. The numbering shown above each block of sequence represents the numbering of the relevant S. cerevisiae protein residue.

interesting that the two occurrences of Am at position 4 are the two isoforms of tRNA ${ }^{\text {His }}$ in S. cerevisiae, which are the only tRNAs of 561 sequenced tRNAs that contain a 2'-Omethylated adenosine residue at any location. By contrast, there are 65 tRNAs containing Um, 141 tRNAs that contain $\mathrm{Cm}$, and 162 that have Gm (Sprinzl et al. 1998).

Analysis of Trm13 protein activity reveals that tRNA binding may be an important factor in determining how Trm13 2'-O methylates its three substrates. Our data demonstrate that Trm13 binds to its tRNA substrates with high affinity $\left(K_{D}\right.$, tRNA $^{\text {Gly }}=100 \pm 14 \mathrm{nM}$ and $K_{D}$, $\mathrm{tRNA}^{\text {His }}=85 \pm 8 \mathrm{nM}$ ) and efficiently catalyzes $2^{\prime}-\mathrm{O}$ methylation of $\mathrm{tRNA}^{\mathrm{His}}$, with a $k_{\text {cat }} / K_{M}$ of $4.0 \times 10^{5}$ $\mathrm{M}^{-1} \mathrm{sec}^{-1}$. Yet, Trm13 exhibits little, if any, detectable binding (Fig. 5) or activity (data not shown) with yeast tRNA species such as tRNA ${ }^{\text {Leu }}$ and tRNA ${ }^{\text {Phe }}$, which are not known to contain the $2^{\prime}$-O-methyl modification at position 4 in vivo. Thus, we suggest that the binding of $\operatorname{Trm} 13$ protein to substrate tRNAs is an important factor in determination of tRNAs that are methylated at position 4. However, it is unclear which features are shared by the three Trm13 substrate tRNAs and/or by the 31 nonsubstrate yeast tRNAs that could account for the differences in modification or perhaps binding. Further experiments and analysis will be required to delineate the specific determinants for tRNA recognition by $\operatorname{Trm} 13$ that are responsible for the selective modification of substrate tRNAs.
The role of 2'-O-methylation of tRNA at position 4 remains to be determined. Structurally, 2'-O-methylation stabilizes the $3^{\prime}$-endo ribose conformation commonly found in A-form RNA (Kawai et al. 1992), although a role such as this in the middle of the acceptor stem might seem unnecessary. Mechanistically, the translocation step of E. coli ribosomes is inhibited by 2'-O-methylation of the acceptor stem at positions 66, 70, or 71 (as well as at 76), or by $2^{\prime}$-deoxy substitution at positions 71 or 76 (Feinberg and Joseph 2001), suggesting different causes of the inhibition. Thus, it is possible that $2^{\prime}$-O-methylation at position 4 of certain tRNAs could be important for one of the steps of translation in yeast. An earlier investigation of phenotypes arising from disruption of seven ORFs in chromosome XV of $S$. cerevisiae showed that there was no phenotype of trm13- $\Delta$ (yol125w) mutants in a variety of conditions, although slower than normal growth of a trm13- $\Delta$ mutant was reported (Hajji et al. 1999), which we do not observe. Despite the lack of phenotype of trm13 mutants, the widespread occurrence in eukaryotes of 2'-Omethylated residues at position 4 of certain tRNAs underscores the importance of this modification on evolutionary timescales. Like mutation of a number of other genes encoding modifications remote from the anticodon, a role for this modification may emerge from study of the appropriate combinations of mutations (Alexandrov et al. 2006) or the appropriate biochemical step. 


\section{MATERIALS AND METHODS}

\section{Growth of strains from the MORF library and purification of proteins}

Strains from the MORF library were grown and purified using IgG Sepharose affinity chromatography as described previously (Gelperin et al. 2005). After cleavage of the bound protein by E. coli-purified GST-3C protease (Alexandrov et al. 2001; Gelperin et al. 2005), the resulting eluted MORF proteins were dialyzed overnight into storage buffer (20 mM HEPES at pH 7.5, $200 \mathrm{mM}$ $\mathrm{NaCl}, 2 \mathrm{mM}$ DTT, $50 \%$ glycerol) and stored at $-20^{\circ} \mathrm{C}$.

MORF-Trm13 was purified by immobilized metal ion affinity chromatography (IMAC) on Talon resin (Clontech) (Gelperin et al. 2005). Crude extracts prepared in CE2 buffer $(20 \mathrm{mM}$ HEPES at $\mathrm{pH} 7.5,1 \mathrm{M} \mathrm{NaCl}, 5 \%$ glycerol, $2 \mathrm{mM} \beta$-mercaptoethanol) containing $2.5 \mu \mathrm{g} / \mathrm{mL}$ pepstatin, $2.5 \mu \mathrm{g} / \mathrm{mL}$ leupeptin, and $1 \mathrm{mM}$ Pefabloc were diluted 1:1 with no salt CE2 buffer, mixed with prewashed Talon resin ( $4 \mathrm{~mL}$ per $500 \mathrm{~mL}$ cells), and mixed for $1 \mathrm{~h}$ at $4^{\circ} \mathrm{C}$. Unbound proteins were removed by low-speed centrifugation, followed by two washes with $10 \mathrm{~mL}$ buffer containing $0.5 \mathrm{M} \mathrm{NaCl}$ and two washes with buffer containing $0.5 \mathrm{M} \mathrm{NaCl}$ and $10 \mathrm{mM}$ imidazole ( $\mathrm{pH}$ 7.7), and then bound protein was eluted with $1 \mathrm{~mL}$ buffer containing $0.5 \mathrm{M} \mathrm{NaCl}$ and $250 \mathrm{mM}$ imidazole $(\mathrm{pH} 7.7)$, followed by dialysis into storage buffer and storage at $-20^{\circ} \mathrm{C}$.

\section{2'-O-methyltransferase activity assay}

$2^{\prime}$-O-methyltransferase activity was assayed with $\left[\alpha_{-}{ }^{32} \mathrm{P}\right]$ labeled tRNA in $10 \mu \mathrm{L}$ reaction mixtures containing $50 \mathrm{mM}$ Tris $\mathrm{HCl}$ (pH 8.0), $2.5 \mathrm{mM} \mathrm{MgCl}_{2}, 1 \mathrm{mM}$ dithiothreitol (DTT), $50 \mathrm{mM}$ ammonium acetate, $0.05 \mathrm{mM}$ ethylenediaminetetraacetic acid (EDTA), $1 \mathrm{mM}$ spermidine, $0.5 \mathrm{mM} S$-adenosyl-methionine (SAM), $\sim 200,000 \mathrm{cpm}\left(6.3 \times 10^{17} \mathrm{cpm} / \mathrm{mol}\right)\left[\alpha-{ }^{32} \mathrm{P}\right]$ labeled tRNA $^{\text {Gly }}$, and a protein source (either crude extract or purified protein). Reactions were initiated by addition of protein, incubated for 5 min to overnight at $30^{\circ} \mathrm{C}$ and then stopped by adding $90 \mu \mathrm{L}$ of buffer containing $0.5 \mathrm{M}$ Tris $\mathrm{HCl}(\mathrm{pH} \mathrm{8.0)}$ and 10-20 $\mu \mathrm{g}$ of carrier RNA, followed by phenol extraction and ethanol precipitation. Then, RNA was treated with either RNase T2 or nuclease P1 as indicated. To produce nucleotide 3 '-monophosphate species, the RNA was resuspended in a $4 \mu \mathrm{L}$ mixture containing $20 \mathrm{mM}$ sodium acetate ( $\mathrm{pH}$ 5.2), 1 mM EDTA, 1 U of RNase T2 (Invitrogen), and $10 \mu \mathrm{g}$ RNase $\mathrm{A}$, incubated at $50^{\circ} \mathrm{C}$ for $1 \mathrm{~h}$, and then treated with $1 \mathrm{U}$ alkaline phosphatase (Roche) for $30 \mathrm{~min}$. To produce nucleotide $5^{\prime}$-monophosphate species, the RNA was resuspended in a $5 \mu \mathrm{L}$ mixture containing $25 \mathrm{mM}$ sodium acetate (pH 5.2), $0.2 \mathrm{mM} \mathrm{ZnCl}_{2}$ and $2.5 \mu \mathrm{g}$ P1 nuclease (MP Biomedicals), and incubated at $50^{\circ} \mathrm{C}$ for $1 \mathrm{~h}$. The digested RNA was then applied to cellulose TLC plates (EM Scientific) and resolved in buffer containing isobutyric acid: $\mathrm{NH}_{4} \mathrm{OH}: \mathrm{H}_{2} \mathrm{O}$ (66:1:33).

\section{Preparation of crude extracts and tRNA from yeast strains lacking Trm13}

The MAT $\boldsymbol{\alpha}$ and MATa haploid trm13- $\Delta$ strains, the homozygous diploid deletion strain (trm13- $\Delta /$ trm13- $\Delta$ ), and its isogenic diploid parent (BY4743) were obtained from Open Biosystems. Preparation of crude extracts by disruption of the yeast cells in the presence of zirconium beads, isolation of low-molecular-weight RNA by hot phenol extraction, and purification of individual tRNA species from the resulting low-molecular-weight RNA using biotinylated oligonucleotide probes (Integrated DNA Technologies) complementary to the tRNA of interest were all performed as previously described (Xing et al. 2004). Probes were:

BioHis for tRNA ${ }^{\mathrm{His}}\left(5^{\prime} /\right.$ Biotin/GCCATCTCCTAGAATCGAACC) BioGly for tRNA ${ }^{\mathrm{Gly}(\mathrm{GCC})}$ (5'/Biotin/TGGTGCGCAAGCCCGGAA

TCAACC)

BioPro for tRNA ${ }^{\text {Pro }}$ (5'/Biotin/GGAATTGAACCCAGGGCCTC TCGCA)

\section{HPLC analysis of nucleosides}

To analyze the individual nucleoside content of each tRNA species, purified tRNA ${ }^{\text {Gly(GCC) }}$ tRNA $^{\text {Pro }}$, or tRNA ${ }^{\text {His }}$ isolated from yeast $(1 \mu \mathrm{g})$ or in vitro transcribed tRNA ${ }^{\mathrm{Gly}(\mathrm{GCC})}(50 \mu \mathrm{g})$ incubated with Trm13 protein were treated with 5-10 $\mu \mathrm{g}$ of P1 nuclease at $37^{\circ} \mathrm{C}$ for $16 \mathrm{~h}$, and then with $8 \mathrm{U}$ of calf intestinal alkaline phosphatase at $37^{\circ} \mathrm{C}$ for $3 \mathrm{~h}$. Nucleosides were resolved by HPLC (Waters Alliance Model 2690, equipped with Waters 996 photodiode array detector) on a reverse phase C18 column as described (Gehrke and Kuo 1989), and modified nucleosides were quantified as described (Jackman et al. 2003; Xing et al. 2004), using either known extinction coefficients for the modified nucleosides where available $\left(\Psi, \mathrm{m}^{5} \mathrm{C}, \mathrm{m}^{1} \mathrm{G}, \mathrm{DHU}\right.$, and $\left.\mathrm{T}\right)$ or using the corresponding extinction coefficients for the unmodified major nucleosides for the species for which this information is not available (Cm, Am).

\section{Primer extension assays}

Primer extension assays were performed essentially as described by Jackman et al. (2003), with $5^{\prime}$-end-labeled primers, using 0.1-0.4 mM of each dNTP (G, A, T, and C) and 0.7 U of AMV-reverse transcriptase (Promega, high concentration) in $1 \times$ AMV-RT reaction buffer (Promega). Reactions were resolved on $10 \%$ polyacrylamide, $4 \mathrm{M}$ urea gels, and visualized using the PhosphorImager (Molecular Dynamics).

\section{Preparation and assay of specifically labeled tRNA substrates}

tRNA $^{\text {Gly(GCC) }}$ was specifically labeled at the $3^{\prime}$ phosphate of $\mathrm{C}_{4}$, essentially as previously described (Yu 1999; Jackman et al. 2003). Briefly, in vitro transcribed tRNA ${ }^{\text {Gly(GCC) }}$ was used as the substrate for RNase $\mathrm{H}$ digestion (RNase $\mathrm{H}$ generously provided by Y.-T. Yu, University of Rochester Medical Center) between residues 4 and 5, as directed by a chimeric oligonucleotide ( $5^{\prime}$-GmCmUmUmGCG CUmCmCmAmUmCmCmAmUmCm-3', HHMI/Keck Synthesis facility, Yale University). After dephosphorylation and rephosphorylation of the $3^{\prime}$ fragment using $\left[\gamma-{ }^{32} \mathrm{P}\right]$ ATP $(\mathrm{ICN}, 7000 \mathrm{Ci} /$ mmol), a synthetic RNA oligonucleotide comprising the first $4 \mathrm{nt}$ of tRNA ${ }^{\text {Gly }}$ (5'-GCGC-3'; Dharmacon Research) was ligated to the $5^{\prime}$ end of the labeled RNA using T4 DNA ligase (USB) and a bridging DNA oligonucleotide, yielding full-length, specifically labeled tRNA ${ }^{\text {Gly }}\left(\mathrm{C}_{4}{ }^{*} \mathrm{Gly}\right)$ after PAGE purification.

tRNA $^{\mathrm{His}}$ specifically labeled at the phosphate following $\mathrm{C}_{3}$ was prepared in a similar method, by RNase $\mathrm{H}$ digestion with a 
different chimeric oligonucleotide (5'-AmAmGmAmUmGGCT CmCmAmGmUmGmCmAmCm-3'). However, since ligation of the 3-nucleotide (nt) $5^{\prime}$ fragment from tRNA ${ }^{\text {His }}$ does not readily occur, the labeled $3^{\prime}$-half-molecule was ligated to a synthetic 18-mer RNA comprised of a 15-residue leader and the first $3 \mathrm{nt}$ of tRNA $^{\text {His }}\left(5^{\prime}\right.$-CCCUGUGCAAGCAACGCC- $\left.3^{\prime}\right)$. This $5^{\prime}$-extended tRNA $^{\text {His }}$ molecule was cleaved in a second $\mathrm{RNase} H$ reaction $(\mathrm{Gu}$ et al. 2003) designed to produce a full-length, specifically labeled, wild-type tRNA $^{\text {His }}\left(\mathrm{C}_{3}{ }^{*} \mathrm{His}\right)$, which was subsequently purified by PAGE.

Reactions with specifically labeled tRNA species were carried out using the same 2'-O-methyltransferase activity assay as described above, except that the RNase T2 digestion products from $\mathrm{C}_{4}{ }^{*} \mathrm{Gly}$ were resolved on PEI-cellulose TLC plates in $0.5 \mathrm{M}$ LiCl. The P1 nuclease products from $\mathrm{C}_{3}{ }^{\star} \mathrm{His}$ were resolved by cellulose TLC in isobutyric acid: $\mathrm{NH}_{4} \mathrm{OH}: \mathrm{H}_{2} \mathrm{O}$ (66:1:33), as was used for the assay of uniformly labeled tRNA ${ }^{\text {Gly }}$ described above.

\section{Purification of $\mathrm{His}_{6}$-Trm13 from E. coli}

To express Trm13 as an N-terminal $\mathrm{His}_{6}$-ORF fusion protein in E. coli, TRM13 DNA was amplified from yeast genomic DNA (derived from strain BY4700, ATCC \# 200,866) with Pfu ultrahigh-fidelity DNA polymerase (Stratagene), and cloned by ligation-independent cloning (LIC) into LIC vector AVA421 derived from pET14b (Alexandrov et al. 2004). The resulting plasmid (pMLW40-1) contained a silent polymorphism at codon 96 of TRM13, which was found to be AAC but is annotated as AAT in the Saccharomyces Genome Database, both of which encode asparagine. After transformation of pMLW40-1 into E. coli BL21(DE3) pLysS cells (Novagen), an individual transformant was grown at $30^{\circ} \mathrm{C}$ in $\mathrm{LB}$ with $100 \mu \mathrm{g} / \mathrm{mL}$ ampicillin to $\mathrm{OD}_{600} 0.5$ and induced overnight at $18^{\circ} \mathrm{C}$ with $1 \mathrm{mM}$ isopropyl $\beta$-Dthiogalactopyranoside. $\mathrm{His}_{6}-\mathrm{Trm} 13$ was purified by IMAC as previously described (Jackman et al. 2003), and the protein was dialyzed into storage buffer containing $20 \mathrm{mM}$ HEPES ( $\mathrm{pH} 7.5$ ), $200 \mathrm{mM} \mathrm{NaCl}, 50 \%$ glycerol, and $2 \mathrm{mM} \beta$-mercaptoethanol for storage at $-20^{\circ} \mathrm{C}$. Trm 13 protein $(3.4 \mathrm{mg} / \mathrm{mL})$ was judged to be $\sim 60 \%$ pure by SDS-PAGE and Coomassie staining.

\section{Electrophoretic mobility shift assays (EMSA) to measure tRNA binding}

Binding of Trm13 protein to tRNA was performed as described (Apostol and Greer 1991) in buffer containing $28 \mathrm{mM}$ HEPES ( $\mathrm{pH}$ 7.5), $40 \mathrm{mM} \mathrm{NaCl}, 5 \mathrm{mM} \mathrm{MgCl}_{2}, 0.5 \mathrm{mM}$ DTT, $2.5 \mathrm{mM}$ spermidine, $50 \mu \mathrm{g} / \mathrm{mL}$ BSA, and $10 \mu \mathrm{g} / \mathrm{mL}$ poly(A) RNA. Binding reactions were incubated for $20 \mathrm{~min}$ on ice, and samples were loaded on a prerun $5 \%$ polyacrylamide gel (49:1 acrylamide:bis) prepared in buffer containing $50 \mathrm{mM}$ Tris borate $(\mathrm{pH} 8.3), 1 \mathrm{mM}$ EDTA, $3 \mathrm{mM} \mathrm{MgCl}_{2}$, and $5 \%$ glycerol, and electrophoresed at $4{ }^{\circ} \mathrm{C}$ in buffer containing $50 \mathrm{mM}$ Tris-Borate ( $\mathrm{pH} 8.3$ ), $3 \mathrm{mM} \mathrm{MgCl}_{2}$, and $1 \mathrm{mM}$ EDTA. Thermodynamic binding data were fit using KaleidaGraph (Synergy software) to a standard binding isotherm (Equation 1), in which the fraction of substrate bound ([E.L]/ $\left.\left[\mathrm{L}_{\text {total }}\right]\right)$, normalized to the endpoint, was plotted against the concentration of enzyme $([\mathrm{E}])$.

$$
\left([\mathrm{E} \cdot \mathrm{L}] /\left[\mathrm{L}_{\text {total }}\right]\right)=1 /\left(1+\mathrm{K}_{\mathrm{D}} /\left[\mathrm{E}_{\text {total }}\right]\right)
$$

\section{ACKNOWLEDGMENTS}

We are grateful to L. Kotelawala for valuable help and discussions and Y. Kon for technical assistance. This research was supported by NIH grant GM52347 to E.M.P.

Received November 21, 2006; accepted December 13, 2006.

\section{REFERENCES}

Alexandrov, A., Dutta, K., and Pascal, S.M. 2001. MBP fusion protein with a viral protease cleavage site: One-step cleavage/purification of insoluble proteins. Biotechniques 30: 1194-1198.

Alexandrov, A., Vignali, M., LaCount, D.J., Quartley, E., de Vries, C., De Rosa, D., Babulski, J., Mitchell, S.F., Schoenfeld, L.W., Fields, S., et al. 2004. A facile method for high-throughput coexpression of protein pairs. Mol. Cell. Proteomics 3: 934-938.

Alexandrov, A., Grayhack, E.J., and Phizicky, E.M. 2005. tRNA m7G methyltransferase $\operatorname{Trm} 8 \mathrm{p} / \operatorname{Trm} 82 \mathrm{p}$ : Evidence linking activity to a growth phenotype and implicating Trm82p in maintaining levels of active Trm8p. RNA 11: 821-830.

Alexandrov, A., Chernyakov, I., Gu, W., Hiley, S.L., Hughes, T.R., Grayhack, E.J., and Phizicky, E.M. 2006. Rapid tRNA decay can result from lack of nonessential modifications. Mol. Cell 21: 87-96.

Altschul, S.F., Madden, T.L., Schaffer, A.A., Zhang, J., Zhang, Z., Miller, W., and Lipman, D.J. 1997. Gapped BLAST and PSIBLAST: A new generation of protein database search programs. Nucleic Acids Res. 25: 3389-3402.

Apostol, B.L. and Greer, C.L. 1991. Preferential binding of yeast tRNA ligase to pre-tRNA substrates. Nucleic Acids Res. 19: 1853-1860.

Balakin, A.G., Smith, L., and Fournier, M.J. 1996. The RNA world of the nucleolus: Two major families of small RNAs defined by different box elements with related functions. Cell 86: 823-834.

Cavaille, J., Chetouani, F., and Bachellerie, J.P. 1999. The yeast Saccharomyces cerevisiae YDL112w ORF encodes the putative 2'O-ribose methyltransferase catalyzing the formation of $\mathrm{Gm} 18$ in tRNAs. RNA 5: 66-81.

Clouet-d'Orval, B., Gaspin, C., and Mougin, A. 2005. Two different mechanisms for tRNA ribose methylation in Archaea: A short survey. Biochimie 87: 889-895.

Corpet, F. 1988. Multiple sequence alignment with hierarchical clustering. Nucleic Acids Res. 16: 10881-10890.

Decatur, W.A. and Fournier, M.J. 2002. rRNA modifications and ribosome function. Trends Biochem. Sci. 27: 344-351.

Decatur, W.A. and Fournier, M.J. 2003. RNA-guided nucleotide modification of ribosomal and other RNAs. J. Biol. Chem. 278: 695-698.

Dunin-Horkawicz, S., Czerwoniec, A., Gajda, M.J., Feder, M., Grosjean, H., and Bujnicki, J.M. 2006. MODOMICS: A database of RNA modification pathways. Nucleic Acids Res. 34: D145-D149.

Feder, M., Pas, J., Wyrwicz, L.S., and Bujnicki, J.M. 2003. Molecular phylogenetics of the RrmJ/fibrillarin superfamily of ribose 2'-Omethyltransferases. Gene 302: 129-138.

Feinberg, J.S. and Joseph, S. 2001. Identification of molecular interactions between P-site tRNA and the ribosome essential for translocation. Proc. Natl. Acad. Sci. 98: 11120-11125.

Gehrke, C.W. and Kuo, K.C. 1989. Ribonucleoside analysis by reversed-phase high-performance liquid chromatography. J. Chromatogr. 471: 3-36.

Gelperin, D.M., White, M.A., Wilkinson, M.L., Kon, Y., Kung, L.A., Wise, K.J., Lopez-Hoyo, N., Jiang, L., Piccirillo, S., Yu, H., et al. 2005. Biochemical and genetic analysis of the yeast proteome with a movable ORF collection. Genes \& Dev. 19: 2816-2826.

Grosjean, H., Sprinzl, M., and Steinberg, S. 1995. Post-transcriptionally modified nucleosides in transfer RNA: Their locations and frequencies. Biochimie 77: 139-141.

Gu, W., Jackman, J.E., Lohan, A.J., Gray, M.W., and Phizicky, E.M. 2003. tRNAHis maturation: An essential yeast protein catalyzes 
addition of a guanine nucleotide to the $5^{\prime}$ end of tRNAHis. Genes \& Dev. 17: 2889-2901.

Gu, W., Hurto, R.L., Hopper, A.K., Grayhack, E.J., and Phizicky, E.M. 2005. Depletion of Saccharomyces cerevisiae tRNA(His) guanylyltransferase Thglp leads to uncharged tRNAHis with additional m(5)C. Mol. Cell. Biol. 25: 8191-8201.

Hajji, K., Clotet, J., and Arino, J. 1999. Disruption and phenotypic analysis of seven ORFs from the left arm of chromosome XV of Saccharomyces cerevisiae. Yeast 15: 435-441.

Hopper, A.K. and Phizicky, E.M. 2003. tRNA transfers to the limelight. Genes \& Dev. 17: 162-180.

Jackman, J.E., Montange, R.K., Malik, H.S., and Phizicky, E.M. 2003. Identification of the yeast gene encoding the tRNA m1G methyltransferase responsible for modification at position 9. RNA 9: 574-585.

Kawai, G., Yamamoto, Y., Kamimura, T., Masegi, T., Sekine, M., Hata, T., Iimori, T., Watanabe, T., Miyazawa, T., and Yokoyama, S. 1992. Conformational rigidity of specific pyrimidine residues in tRNA arises from posttranscriptional modifications that enhance steric interaction between the base and the $2^{\prime}$ hydroxyl group. Biochemistry 31: 1040-1046.

Keith, G., Pixa, G., Fix, C., and Dirheimer, G. 1983. Primary structure of three tRNAs from brewer's yeast: tRNAPro2, tRNAHis1 and tRNAHis2. Biochimie 65: 661-672.

Kiss-Laszlo, Z., Henry, Y., Bachellerie, J.P., Caizergues-Ferrer, M., and Kiss, T. 1996. Site-specific ribose methylation of preribosomal RNA: A novel function for small nucleolar RNAs. Cell 85: $1077-1088$.

Lafontaine, D.L. and Tollervey, D. 1999. Nop58p is a common component of the box $\mathrm{C}+\mathrm{D}$ snoRNPs that is required for snoRNA stability. RNA 5: 455-467.

Lafontaine, D.L. and Tollervey, D. 2000. Synthesis and assembly of the box C+D small nucleolar RNPs. Mol. Cell. Biol. 20: 2650-2659.

Lapeyre, B. and Purushothaman, S.K. 2004. Spb1p-directed formation of Gm2922 in the ribosome catalytic center occurs at a late processing stage. Mol. Cell 16: 663-669.

Limbach, P.A., Crain, P.F., and McCloskey, J.A. 1994. Summary: The modified nucleosides of RNA. Nucleic Acids Res. 22: 2183-2196.

Maden, B.E., Corbett, M.E., Heeney, P.A., Pugh, K., and Ajuh, P.M. 1995. Classical and novel approaches to the detection and localization of the numerous modified nucleotides in eukaryotic ribosomal RNA. Biochimie 77: 22-29.

Pintard, L., Bujnicki, J.M., Lapeyre, B., and Bonnerot, C. 2002a. MRM2 encodes a novel yeast mitochondrial 21S rRNA methyltransferase. EMBO J. 21: 1139-1147.
Pintard, L., Lecointe, F., Bujnicki, J.M., Bonnerot, C., Grosjean, H., and Lapeyre, B. 2002b. Trm7p catalyses the formation of two 2'O-methylriboses in yeast tRNA anticodon loop. EMBO J. 21: 1811-1820.

Renalier, M.H., Joseph, N., Gaspin, C., Thebault, P., and Mougin, A. 2005. The Cm56 tRNA modification in archaea is catalyzed either by a specific $2^{\prime}$-O-methylase, or a C/D sRNP. RNA 11: 1051-1063.

Schimmang, T., Tollervey, D., Kern, H., Frank, R., and Hurt, E.C. 1989. A yeast nucleolar protein related to mammalian fibrillarin is associated with small nucleolar RNA and is essential for viability. EMBO J. 8: 4015-4024.

Schubert, H.L., Blumenthal, R.M., and Cheng, X. 2003. Many paths to methyltransfer: A chronicle of convergence. Trends Biochem. Sci. 28: 329-335.

Sprinzl, M., Horn, C., Brown, M., Ioudovitch, A., and Steinberg, S. 1998. Compilation of tRNA sequences and sequences of tRNA genes. Nucleic Acids Res. 26: 148-153.

Tyc, K. and Steitz, J.A. 1989. U3, U8 and U13 comprise a new class of mammalian snRNPs localized in the cell nucleolus. EMBO J. 8: 3113-3119.

Watkins, N.J., Segault, V., Charpentier, B., Nottrott, S., Fabrizio, P., Bachi, A., Wilm, M., Rosbash, M., Branlant, C., and Luhrmann, R. 2000. A common core RNP structure shared between the small nucleoar box C/D RNPs and the spliceosomal U4 snRNP. Cell 103: 457-466.

Wu, P., Brockenbrough, J.S., Metcalfe, A.C., Chen, S., and Aris, J.P. 1998. Nop5p is a small nucleolar ribonucleoprotein component required for pre-18 S rRNA processing in yeast. J. Biol. Chem. 273: 16453-16463.

Xing, F., Martzen, M.R., and Phizicky, E.M. 2002. A conserved family of Saccharomyces cerevisiae synthases effects dihydrouridine modification of tRNA. RNA 8: 370-381.

Xing, F., Hiley, S.L., Hughes, T.R., and Phizicky, E.M. 2004. The specificities of four yeast dihydrouridine synthases for cytoplasmic tRNAs. J. Biol. Chem. 279: 17850-17860.

Yoshida, M. 1973. The nucleotide sequency of tRNA Gly from yeast. Biochem. Biophys. Res. Commun. 50: 779-784.

$\mathrm{Yu}$, Y.-T. 1999. Construction of 4-thiouridine site-specifically substituted RNAs for cross-linking studies. Methods 18: 13-21.

Yu, Y.-T., Terns, R.M., and Terns, M.P. 2005. Mechanisms and functions of RNA-guided RNA modifications. In Fine-tuning of RNA functions by modification and editing, Topics in Current Genetics series (ed. H. Grosjean), vol. 12; pp. 223-262. SpringerVerlag Press, New York. 

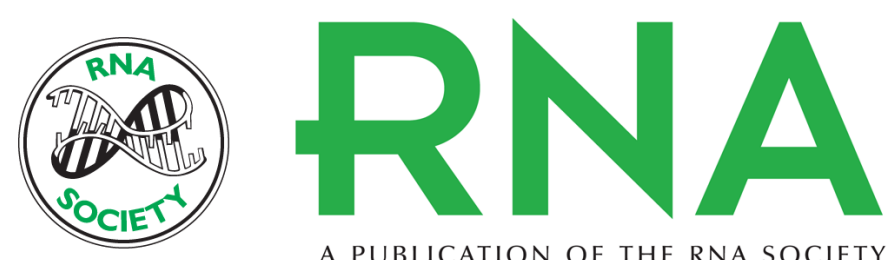

A PUBLICATION OF THE RNA SOCIETY

\section{The 2'-0-methyltransferase responsible for modification of yeast tRNA at position 4}

Martha L. Wilkinson, Sharon M. Crary, Jane E. Jackman, et al.

RNA 2007 13: 404-413 originally published online January 22, 2007

Access the most recent version at doi:10.1261/rna.399607

References This article cites 45 articles, 18 of which can be accessed free at:

http://rnajournal.cshlp.org/content/13/3/404.full.html\#ref-list-1

License

Email Alerting Receive free email alerts when new articles cite this article - sign up in the box at the

Service top right corner of the article or click here.

To subscribe to RNA go to:

http://rnajournal.cshlp.org/subscriptions 